\title{
MUCH ADO ABOUT NOTHING: THE ITALIAN GEOLOGICAL SURVEY, 1861-2006
}

\author{
Pietro Corsi
}

History Faculty, University of Oxford, Oxford, U.K. (pietro.corsi@history.ox.ac.uk)

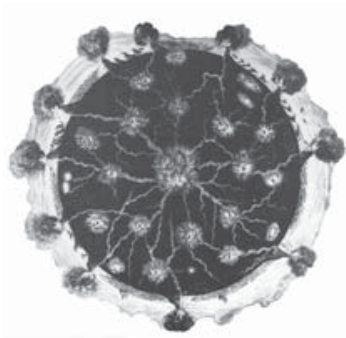

Earth Sciences History, v. 26, no. 1, 2007, pp. $97-125$.

\begin{abstract}
Established on 12 December 1861, soon after the proclamation of the Kingdom of Italy in January 1861, the Geological Survey of the peninsula enjoyed a remarkably difficult life, and achieved remarkably little. Since its inception, the rivalry between academic geologists and the engineers of the Royal Mining Corps acting as field surveyors did much to alienate political and public opinion support. Underfunded and understaffed, the Survey faced periodical crisis and periodical reforms. On at least four occasions $(1861,1873$, the early 1920s and 1960), the help of influential politicians concerned with the lack of a functioning State Survey, or with the very slow pace of publication of the geological map of the country, produced beneficial effects and brisk activity. This never lasted longer than a few years. In the last four decades of the twentieth century, the growth of the politically powerful community of geophysicists and the lack of political initiative and Parliamentary supervision further marginalized the Geological Survey, up to its relegation to a subordinate role within the State Agency for the Protection of the Environment.
\end{abstract}

\section{INTRODUCTION}

The historiography of science (particularly of geology), as well as the historiography concerned with the early formation of the Italian State, has paid scant attention to the complex history of the Italian geological survey. Indeed, great uncertainty still prevails as to the timing and authorship of the project to provide the new Italian State, formally constituted as Regno d'Italia on 1 January, 1861, with a geological map. There is an excellent, ground-breaking biography of Quintino Sella (1827-1884), the wealthy Piedmontese scientist-turned-politician who was one of the major actors in the early history of the Survey. However, it mentions only in passing Sella's involvement in the rapid succession of events, starting in July 1861, which led to the Royal decree of 12 December of that year, officially launching the enterprise of a geological map of the country (Quazza 1992, p. 356). Yet official publications and the official website of the Servizio Geologico, the successor of nineteenth-century State surveying agencies, give 1867 as the starting date (Carusone et al. 1996). ${ }^{1}$ As I shall argue below, this is only partially correct. Documents recently rediscovered after decades of neglect, as well as photocopies of archival documents made during the 1990s at the historic building of the

\footnotetext{
1 Topley 1885 gives 1868; Guntau 1988, p. 57 also gives 1868. For a general survey of Geological mapping
} enterprises, see Oldroyd 1996. 
Geological Service in Rome (Largo di Santa Susanna, now under renovation), have proven crucial after the seeming disappearance of their originals in the early 2000s. They throw a dramatic and fascinating light on the history of one of the least studied episodes in the troubled relationship between the modern Italian State and scientific, specifically geological, practices. ${ }^{2}$

Constantly under attack, under-funded, and understaffed, during the last decades of the nineteenth century and the first two of the twentieth, senior officials in charge of the Geological Survey produced historical accounts of the difficulties they experienced. They were repeatedly asked to justify their slow pace of publication, the poor quality of the maps produced, and the lack of uniformity both in the scales adopted and in the criteria that were deployed in their compilation (Millosevich 1931). In order to do so, they wrote and re-wrote the history, or perhaps more accurately, the chronicle of their institution. They listed the founding decrees, successive legislative interventions intended to remedy faults and vices, and the three or four new fresh starts, each repeatedly announced as, at last, the 'good one' (Zezi 1876; Cermenati 1891; Pellati 1895 and 1904; Millosevich 1931). On the whole, the lists of decrees that compose much of these chronicles pose few problems in terms of accuracy, as they are based on Acts of Parliament and on accessible printed material. Yet, for reasons that will be reconstructed below, these early chronicles, and the historians who have taken them at face value, make no reference to the fact that the Geological Survey of Italy was established in the early weeks of 1862 . Already at this point, a Director had been appointed, a permanent staff selected, and recruiting procedures outlined. Moreover, operational plans had been agreed upon, including the crucial political choice of a location for the headquarters and its attached museum for collections, intended as a complement to field surveying.

It is important to recognise that the "official" histories were based on the archival material available to their authors, all senior Survey staff. This material, it should be added, was impeccably preserved, carefully catalogued, and repeatedly summarised in detailed chronologies of events. These summaries were intended for submission to various ministers or politicians likely to take action on behalf of the Geological Survey, or to answer the increasingly vociferous critics from the floor of Parliament and the press. Thus, when contemporary and later official commentators wrote that the country's financial difficulties prevented the 12 December, 1861 decree from being put into effect, they were deliberately failing to tell their readers that the documents at their disposal told a different story: the Geological Survey of the Kingdom had been established following the Royal decree. In order to fully understand the reasons for this omission, the series of events leading to the Royal Decree of December 1861 and its immediate aftermath must be narrated. The complex politics of the beginning of the Geological Survey of Italy, once unravelled, will help explain much of what followed.

2 Archivio Centrale dello Stato, MAIC 4194, 1, 2, 3. Carusone et al. 1996; Eramo1995. While in press, Dr Emi Morroni, formerly in charge of the Library of the Geological Survey and now Head of Department at the Agency for the Protection of the Environment (Apat), has kindly informed me that more files of the historic Archive have been recently found in a locked cupboard. Preliminary examination of this important addition to primary sources relating to the Geological Survey of Italy that I undertook on 27--30 December 2006 has led to the acquisition of digital copies of about 4,500 ms. pages, out of a total of approximately 30,000. It is important to emphasize that this newly found archive does not appear to contain all the documents photocopied during the 1990s and now available on the Histmap website: http:// www.hstl.crhst.cnrs.fr/i-corpus/histmap 


\section{LOCAL TRADITIONS AND NATIONAL HOPES}

It is outside the scope of the present study to detail the mapping enterprises conducted by Italian geologists active in the early decades of the nineteenth century. It is sufficient to recall that Italian geology had a distinguished past and still enjoyed a prestigious reputation in 1830. In the historical introduction to the first volume of his Principles of Geology, Charles Lyell commented on the crucial importance of eighteenthcentury Italian geologists to the development of the discipline (McCartney 1976). It could hardly be claimed, however, that this was still the case by 1840 . Practitioners of geology had not disappeared from the peninsula (which was still divided in several independent States, subject to different political, economic, and administrative regimes): far from it. The heirs to Anton Lazzaro Moro (1687-1764), Giovanni Arduino (1714-1795), Lazzaro Spallanzani (1729-1799), Scipione Breislack (1748-1826), Giovanni Battista Brocchi (1772-1826), and Giuseppe Marzari Pencati (1779-1836) were still active in the national and the international scene. Many of them were members of the Société géologique de France, established in 1830, and they published in its prestigious Bulletin. Nevertheless, they travelled less extensively than in the last decades of the eighteenth century, had more limited correspondence with their European colleagues, and suffered the backlash of the Restoration in 1815 by pre-Revolutionary and pre-Napoleonic regimes. These crushed or reduced to near insignificance the scientific and technological modernisation of local and national administrations, which had been timidly but efficiently put into action during the French-led administration (Pasta 1989; Vaccari 1993 and 1998; Barsanti et al. 1996; Corsi 1998).

Beginning in 1839, the annual meetings of Italian scientists gave local geologists ample opportunity to interact personally with the discipline's European luminaries. Leopold von Buch (1774-1853), Élie de Beaumont (1798-1874), or Jean-Baptiste Julien d'Omalius d'Halloy (1783-1785, who at the time was more famous and influential than historians now realise) were shown around the classic localities of the peninsula, from the Alps to Mt Etna and Vesuvius, the Venetian hills, and the Alpi Apuane, the marble mountains of Tuscany (Pancaldi 1983; Garin 1991). As I have argued elsewhere, a lack of collections, books, and financial support for field-work forced the great majority of Italian geologists to practise almost within walking distance of their home-town or university. Some turned this necessity into a virtue, contending that geology could only be local. Foreign travellers and amateurs passing by could never gain an adequate understanding of the structure of regions that several decades of detailed and devoted study by local naturalists and geologists had failed to unravel (Corsi 1998 and 2001). Moreover, the oft-repeated myth that our current centre-periphery dichotomy already prevailed in the first half of the nineteenth century does not take into account the all important social procedures allocating reputations at the local level, and the complex dialectic of maintaining contact with foreign colleagues. Thus, with few exceptions, Italian geologists did not suffer from any perceptible 'inferiority complex' with respect to their more privileged and better-funded French, German, or British colleagues. Their international prestige had diminished, but their pride had not (Corsi 2003b).

Cartographic efforts conducted elsewhere in Europe and beyond the old Continent were well known to Italian geologists, and were occasionally emulated. However, the lack of topographic maps for several regions (included the entire South of the peninsula) often limited such efforts to sketchy overviews on very small scales. Wealthier states like the Kingdom of Sardinia, or Lombardy and the Venetian regions under Austrian 


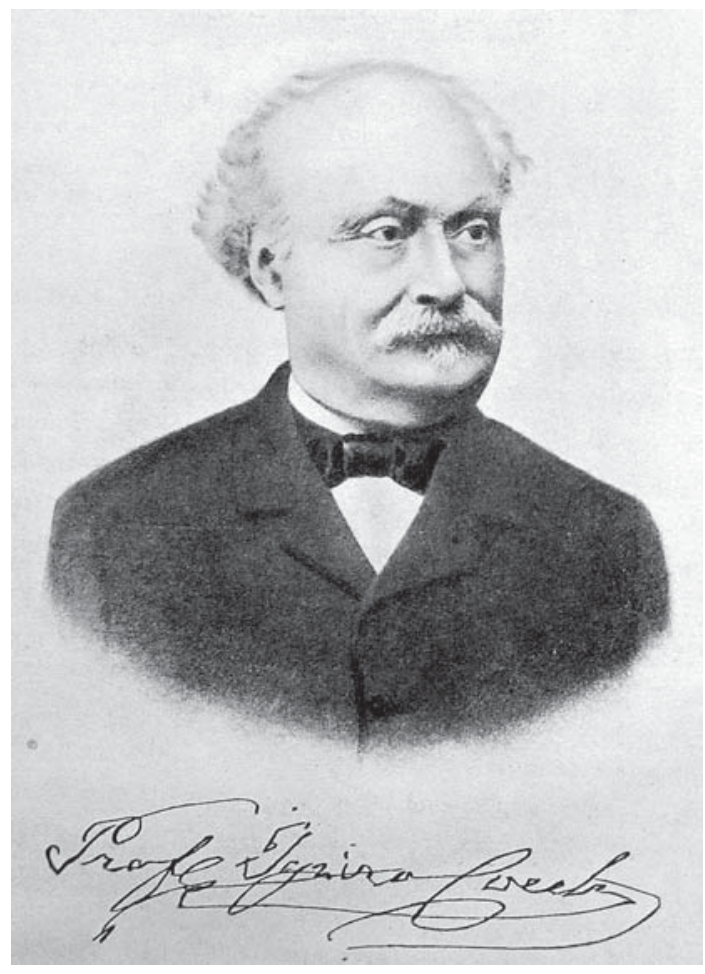

Figure 1. Igino Cocchi (1827-1913), founder and head of the Geological Committee, 18671873.

administration (or occupation, as the Risorgimento rhetoric would prefer) had started their own geological mapping enterprises, stemming from a variety of initiatives and responding to a variety of economic, theoretical, and symbolic needs. The pioneering geological map of Sardinia (published in 1857) by General Alberto della Marmora(1789-1863) was, however, the result of his determination and personal wealth rather than of governmental choice. Similarly, the creation of a geological map of the Stati di Terraferma (continental Piedmont) under the leadership of Angelo Sismonda (1807-1878), initiated in October 1846, and finally published in 1867 , was more of a reflection of the combination of personal ambition and networking skills on the part of the geologist than an indication of the Government's conversion to large-scale, state-financed surveys. Finally, it is worth mentioning that authors of local geological maps did not boast about them, nor appear to have used them for training or teaching purposes. Igino Cocchi (1827-1913) (Figure 1), a pupil of Giuseppe Meneghini (1811-1889) and of Paolo Savi (1798-1871), appears never to have studied or used the later celebrated geological map of the Monti Pisani which Savi had hand-coloured in the 1830s: he had only seen it once. ${ }^{3}$ Financial resources and usages were thus at the individual level (Cocchi 1871). No provision for collections, museums, or specialised libraries entered the horizon of these or similar enterprises in any significant way. For Lombardy and the Venetian regions, the Imperial administration in Vienna took care of topographical and geological mapping. Franz Ritter von Hauer (1822-1899) headed the geological survey of Lombardy, whereas Frantisek Foetterle (1823-1876) worked on the Venetian regions. Indeed in 1867, when the Comitato Geologico led by Igino Cocchi began its operations, it was forced to appeal to the hated Austrians for the only reasonable (and often very good) topographic maps available for Lombardy, the Venetian regions, Tuscany, the Pope's possessions in the Po plains (Bologna, Ferrara) and small States like Modena and Parma (Corsi 2001).

A long rhetorical tradition existed, in Italy as elsewhere, of extolling the benefits of pursuing geological studies. The creation of the chair of geology in Pisa, conferred to the

3 Archivio Meneghini, I. Cocchi to G. Meneghini, Paris, 15 May 1855, f. 2r: "A Geological Map of Tuscany does not exist: could I have some fragments, such as the map of the Pisan Mountains that I have seen at Paolo Savi's, at least for a short time? This would be highly appreciated by myself and many others." 
Neapolitan Leopoldo Pilla (1805-1848) in 1841, was decided by the Grand Duke Leopold II himself. The Grand Duke desperately hoped that Tuscany would become the Saxony of the South, rich as it was - he often repeated - in all sorts of minerals; and, more excitingly, providentially endowed with a thick layer of coal beams on which to ground the future prosperity of the state. Yet, no coalfield was to be found beneath the Tuscan hills. Pilla had undertaken a partially successful search for minerals in the Neapolitan regions, and had attracted the attention of the Queen of Naples (the Tuscan Grand Duke's sister), who opened the way for the prestigious appointment (Corsi 2001). Tuscan and Northern geologists often acted as counsellors to local mining ventures, although the practice of systematic excursions was rare and, as previously mentioned, most often covered a very limited geographical range.

Even the enthusiasm surrounding the early proposal to work collectively on a geological map of the Italian peninsula, formulated during the first meeting of Italian scientists held in Pisa in 1839, produced little effect (Atti I 1840, pp. 74, 110). Agreement was reached to adopt the chromatic scale used by Élie de Beaumont and Armand-Pierre Dufrénoy (1792-1857) for their general map of France, with the self-serving support of von Buch, who had inspired the initial French choice. A central collection of minerals, fossils, and maps was to be established in Florence, under the aegis of the Grand Duke at the end of the Third Congress of Italian scientists, held in the Tuscan capital in 1841. It was announced that the collection would represent the first step towards the achievement of a geological map of the peninsula. However, the project did not outlive the proclamation. Indeed, unanimous agreement regarding the necessity of a collaborative effort did not prevent rivalries or fierce competition. At the Fifth Congress of Italian scientists held in Milan (1844), Giacinto Ottavio Collegno di Provana (1794-1856), who had immigrated to Bordeaux, where he was teaching botany, geology, and mineralogy, produced his own map on the scale of $1: 2,000,000$. His publication of the map in Paris, without consulting his colleagues, raised many eyebrows and caused much irritation (Atti III 1841, p. 165; Atti IV 1843, p. 397; Atti V 1844, p. 227; Atti VI 1845, p. 584).

\section{PRIORITY DISPUTES}

The manuscript correspondence of Italian geologists that I have gained access thus far does not appear to contain evidence of any determined effort to engage in the creation of a geological map of the Italian peninsula. During the 1870 s and the 1880 s, Igino Cocchi and Felice Giordano (1825-1892) (Figure 2) claimed, or were at least rumoured, to have initiated the national geological survey project in the late 1850s and in 1860-1861. However, they could not produce more than scanty evidence of the advice they had provided to, or the promises they had obtained from, their governments. In short, they offered nothing more than suggestions.

Thus Igino Cocchi, a chief protagonist in the early history of the Geological Survey of Italy, boasted that, upon his return in 1857 from a four-year stay in Paris and London, he had proposed the creation of a private association of naturalists, geologists, mining interests, and venture capitalists in Florence to conduct a geological survey of Tuscany in an effort to enhance mining and general industry (Cocchi 1871; Zezi 1876; Baldacci 1911; Corsi 2003c). His correspondence with geological colleagues in Pisa, and especially with Giuseppe Meneghini, his teacher and at times reluctant mentor, neither substantiates nor refutes Cocchi's claim. However, it is curious that no mention of so ambitious an undertaking is to be found in letters to his Pisan senior colleagues, who would have 


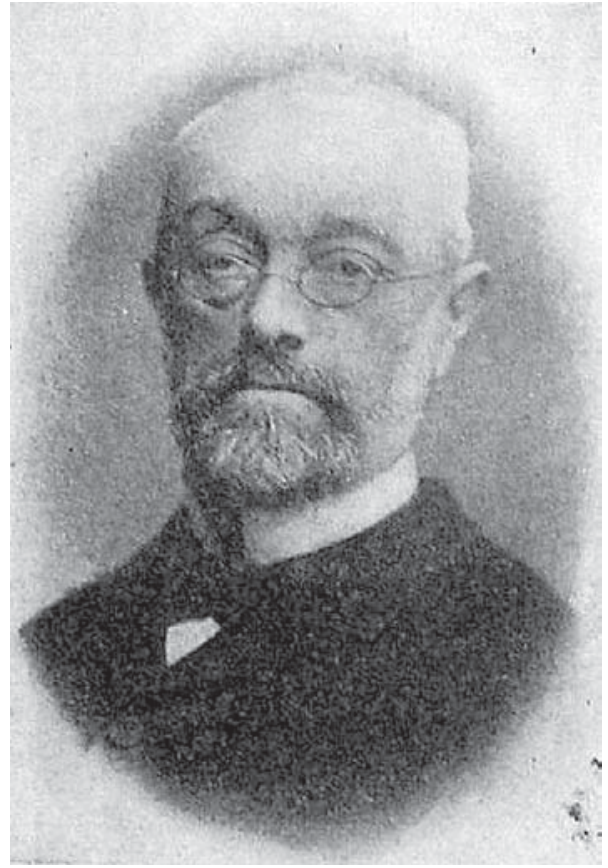

Cocchi took charge of the Museum in 1861 and the Geological Survey in 1867.

As far as Giordano was concerned, officers of the Corps of Mining Engineers did not tire of repeating that a letter Giordano had sent to the Ministry of Agriculture in October 1860 sparked off the initial project of a national Geological Survey. Yet the fact that no trace of the letter was ever found in the well-kept archives of the Ministry, and no quotation from it was ever provided by those who claimed to have seen it, led contemporaries - and historians - to question its very existence. Giordano himself never referred to it, and it is possible that mining engineers took a document that Giordano wrote on 19 October 1860 (to oppose an anonymous project for a Geological Survey to be entrusted to academic geologists) as the founding document of the Corps' early involvement with the Survey (Zezi 1876; Cermenati 1891; Baldacci 1911; Capellini 1911, p. 179; Cermenati 1918, p. 362; Corsi 2003c).

\section{A NEW STATE, A NEW START}

The nationalistic feelings of the late 1850 s, the eruption of the second war of Independence in 1859, and the impressive conquest of the South of Italy by Giuseppe Garibaldi in 1860 galvanized citizens and scientists alike. The new Kingdom of Italy, unified under the crown of Piedmont, was established at the beginning of 1861. By July, the Minister for Agriculture, Industry and Commerce, Filippo Cordova (1811-1868), had already started working at his pet project: a geological map of his native Sicily, to enhance the sulphur industry. He had also begun an even larger project: the geological map of the

4 Archivio Centrale dello Stato, Rome, MAIC 4194, 1. See also Cocchi to Cordova, 5 July 1861, MAIC 4194, 1. 
entire peninsula. ${ }^{5}$ In the words of Lyell, someone who knew his business, geology had once been an Italian science. Almost every pre-Unity State could boast a local geological authority, and in a few cases their names were known as far as Vienna, Paris, London, and Berlin. Every European power was then publishing its own geological map. Italy would not lag behind. The new Kingdom, Cordova personally explained to the King, could and should do better than the scattered pre-Unity states, which were often dominated by predatory foreign dynasties:

Italian science and the Italian motherland do not lack precious studies on the geognosy of our provinces. Yet, it is sufficient to peruse them the one after the other, in order to see the deep traces of the abandon and anarchy that lowered all the products of contemporary Italian civilisation. This was due to the will or the lamentable state of the Governments that have just fallen, or to the very fact that these [pre-unity] States were too numerous, isolated, and different from one another. Maps on different scales and proportions [were produced], inspired by conflicting scientific faiths, of more or less authoritative origin, dispersed in big and small monographs, forgotten in thick proceedings of scientific societies, conceived and executed without any order or agreement on the typographical criteria or systems to be followed, compiled with different aims in view, drawn with varying degrees of accuracy, and all, by the way, insufficient for public service, because of the inadequate proportions adopted, and the almost constant omission of all reference to subterranean features like springs, mines, quarries, fossil depots. ${ }^{6}$

A national preliminary conference, held in Florence during the first two weeks of September, 1861, revealed the difficulty of the task. Cordova had relied on a young Piedmontese crystallographer and mineralogist, Quintino Sella, a man on the rise in the new national political scene, to get things done. A diplomat of the University of Turin, Sella had studied at the École des Mines in Paris from 1848 to 1851. As head of a major family-owned textile industry, he liked to get things done efficiently. ${ }^{7}$ Yet even Sella's no-nonsense approach and diplomatic shrewdness could not conceal the fact that eminent provincial geologists, who were formerly the masters of their discipline within their local State, were not prepared to accept the leadership of the new ruling Piedmontese scientific and political élite. Sella was in favour of a centralized Geological surveying authority, modelled either on the London or Austrian Surveys, which would be manned and ruled by officers who were mining engineers of the predominantly Piedmontese Corps of Mines. Furthermore, the majority of geologists, naturalists by training and taste, were unwilling to take instructions from engineers, who, they believed, knew little of geology. This conflict was to loom large over the history of the Survey.

The conclusions of the Florentine conference, printed in a Report submitted to the Minister of Agriculture, favoured the establishment of a centralized office, provided that it was under the close supervision of a Council composed of university and amateur

5 Sicilian politician, amateur geologist, top-ranking Freemason, and close friend of the German geologist Hermann Wilhelm Abich (1806-1886), Cordova was Minister of Agriculture, Industry and Commerce from 12 June, 1861, to 3 March, 1862, in the Cabinet led by Bettino Ricasoli. He held the same post in the second Ricasoli Cabinet, from 20 June, 1866 to 10 April, 1867. Ministers often held office for only a few months, which increased the power of the Director General and high ranking staff in the ministerial bureaucracy. See Cordova 1889-1993.

6 Archivio Centrale dello Stato, MAIC 4194, 1, ff. 17r - 17v, printed version, f. 23v).

7 Quazza 1992 is surprisingly silent on Sella's involvement with the Geological map of Italy; Vernizzi 1986. The Sella Foundation, Biella, preserves the rich and well kept Archive of the Piedemontese scientist and politician. I wish to thank the Foundation and its staff for their generous assistance over several years of research. 
geologists, to whom the Director of the Survey would have to defer. Back from a journey undertaken early in November 1861 to collect information and maps from major geological surveys in Europe, Sella wrote his own report, overturning the Florentine conference agreement. He proposed that a Geological Survey be established at Valentino Castle in Turin, the capital of the new Kingdom. The scheme was approved by the Minister, and on 12 December, 1861, the King signed the decree that formally initiated the Geological Survey of Italy. On 5 January, 1862, Sella was appointed Director answering only to the Minister in person, as he had requested. Sella selected his own staff, and made provisions to send senior surveying personnel to London, where the Geological Survey had offered to train them for one or two years as appropriate. Thus, despite some friction, things began after all. But the problem was that momentum only lasted a few weeks (Corsi 2003c). ${ }^{8}$

\section{THE COCCHI ERA: 1867-1873}

Soon after his nomination to the head of the Geological Survey of Italy, on March 3,1862 , Sella was asked to occupy on three almost consecutive occasions one of the most uncomfortable seats in the Council of Ministers: that of the Finances. The new Kingdom of Italy was near collapse. During his tenure, Sella restored budgetary balance, and became one of the most respected (yet unpopular) Ministers of the political class that had unified the peninsula. ${ }^{9}$ It was said that he deliberately froze the credits of the Geological Survey which he himself had started; some thought this was to preserve the then prestigious job for later times, since it was common knowledge that Ministers did not last long in office (Corsi 2003). The official papers do not dispel the ambiguity. Sella continued to sign payment orders for work undertaken at Valentino Castle well into 1864, calling himself the Director of the Survey. Yet, whatever the reasons, the dormant project was taken up again by Cordova, who returned briefly to the Ministry of Agriculture in June 1866. By then Florence had become the capital of the New Kingdom - and in Florence lived Igino Cocchi (Corsi 1982).

Wealthy, well travelled, and conversant in the main European languages, Cocchi (as mentioned above) had himself tried to set up a consortium of private citizens and mining interests to produce a geological map of Tuscany in the late $1850 \mathrm{~s}$, with an eye to attracting foreign investments. Appointed Secretary to the 1861 Florence geological conference, he fought in vain against Piedmontese supremacy and was disillusioned by

8 In a letter dated January $1^{\text {st }}, 1862$, Cordova offered Sella the position of Director General of the Geological Survey of Italy, Archivio Centrale dello Stato, MAIC 4194, 3, f. 198r. Sella accepted on 5 January, 1862, on the condition that he should receive no salary (as a Member of Parliament, he could not accept any remuneration) and that he could choose with whom to work: "In truth, while Your Excellency is at the head of the Ministry of Agriculture, Industry and Commerce ... I would not need to ask to be allowed to make proposals, since I well know that you have always accepted with great amiability my advice, but more particularly since you know by experience how a geological map is executed. But when the Ministry which you now direct, falls into other hands, I should be comforted in the difficult task you are asking me to take upon myself, if it were established that on all matters relating to the personnel of the geological map the Minister will hear the advice of the Director, who will naturally leave to the Minister's political wisdom to decide as he will deem it appropriate": Archivio Centrale dello Stato, MAIC 4194, 3, ff. 201r - 202v, 205r. On Sella's plans for the hiring of the surveying staff, see Archivio Centrale dello Stato, MAIC 4194, 3, ff. 204r-210v, Sella to Cordova, 15 January 1862.

9 Sella was Minister of Finances from 3 March, 1862, to 8 December, 1862; then again from 23 September, 1864, to 31 December, 1865, and from 14 December, 1869 to 10 July, 1873. 
the outcome. After a few attempts to convince the central Government to finance a further project he proposed (a geological map of the Apuane Alps and their rich marble quarries) Cocchi managed to convince Cordova that a Geological Survey could be started based upon the Portuguese model. All it would take was a little money and a lot of generous private contributions. On 18 February, 1866, a Geological Section was established within the Council of Mines to make preparations for a general geological survey of the Kingdom. The Committee was composed of Cocchi, his mentor Giuseppe Meneghini, and Giuseppe Scarabelli (1820-1905), a pupil of Pilla at Pisa and friend of both Meneghini and Cocchi. Thus Tuscan geologists were taking their revenge on the Piedmontese school; but action was slow to follow. It can be argued that this was prompted by the swift reaction of the Piedmontese 'clan' to the coup that their Tuscan rivals had successfully staged.

In the late summer of 1866 Giordano was asked to organize the mineralogical and industrial sections of the Italian displays for the Paris 1867 exhibition. He proposed that a geological map of Italy on a small scale should be exhibited, to show that the new Kingdom did not neglect so crucial a sector of contemporary state-financed science. A few letters between Felice Giordano and Igino Cocchi from September to December 1866 (kindly put at my disposal by Fausto Barbagli), reveal that Giordano suggested that either the palaeontologist and geologist Antonio Stoppani (1824-1891) or the geologist and mineralogist Bartolomeo Gastaldi (1818-1879) - both indicated by Sella as chief surveying officers in the plan the latter submitted to Cordova in 1862 - be put in charge of preparing the Exhibition's geological map of Italy. Giordano had also asked his friend Giulio Axerio (1830-1880), a collaborator with Sella and Head of the Mining District of Milan, to keep a watch on what was going on while he was in Paris preparing for the Exhibition. Axerio was temporarily transferred from Milan to the Central Office of the Mining Corps at the Ministry of Agriculture in Florence.

Giordano's letter to Cocchi in early October 1866 (probably written to inform his colleague in Florence that the Commission organizing the Paris exhibition had already made its decision), convinced Cocchi that no time could be lost. Though only indirect evidence is available, the fact that on 24 November, 1866 Cordova wrote an official note to Cocchi ordering that the Geological Section at the Council of Mines also prepare a map for the Paris exhibition, and that on 14 November, 1866, Giordano - clearly unaware of what was going on at the Ministry - bitterly complained to Cocchi that Cordova had ordered Axerio to leave the capital and return to his mining district in Milan, suggests that Cocchi had successfully outmanoeuvred his Piedmontese colleagues. ${ }^{10}$ It was however only on 15 December, 1867 that the Geological Section was finally transformed into the Comitato Geologico, and formally charged with the preparation and publication of the Geological Map of the Kingdom. ${ }^{11}$

${ }^{10}$ Archivio Cocchi, F. Giordano to I. Cocchi, n.d. (but early October 1866): “As far as geological maps are concerned, no special commissioner has yet been appointed. It would be appropriate to nominate someone who would not exhibit his own maps. As far as the general map of Italy is concerned, there are difficulties. Stoppani does not want to do it. Gastaldi could perhaps take the job upon himself. We will do our best." Archivio Cocchi, F. Giordano to I. Cocchi, 14 novembre 1866, "I have heard with sorrow that the Ministry has sent Axerio back to his Milan District."

11 Zezi 1876 offers a different, 'official' reconstruction: it was Giordano who suggested to the Minister that Cocchi and his Committee should be given the task of preparing the geological map for the Paris exhibition. The letters we have quoted contradict this reconstruction. 


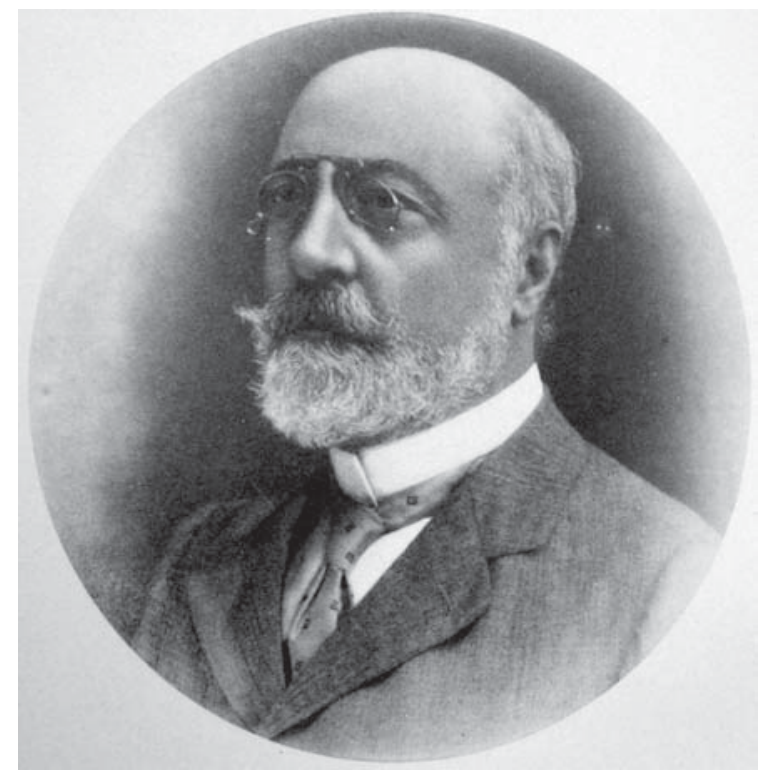

Figure 3. Pietro Zezi (1844-1914), Secretary to the Geological Committee, 1869-1903, and managing director of the Geological Survey.

Yet ministerial decisions and orders proved ineffective: over and over again in the history of the geological survey of Italy governmental decrees were rarely implemented. ${ }^{12}$ In 1866 and 1867, a variety of problems delayed the organization of the infrastructure for the Geological Committee, which was now working against a sensitive political deadline. A couple of rooms in a popular street of Florence were finally obtained, and the mining engineer Pietro Zezi (1844-1914) (Figure 3) was appointed secretary to the Committee. He occupied this post - the only one paid for by the Ministry - until 1908, before retiring from active service in 1911. Cordova was dismissed in April 1867, and Cocchi had to start all over again, working with several new Ministers, each of whom remained in power for a limited time (sometimes less than a year) and knew little about, and cared even less for, geology. Yet the approaching World Exhibition in Paris was an occasion not to be missed. It would have been a scandal, Cocchi argued, if Italy could not produce a sample of its proficiency in geological matters. A plan was hastily drawn up to prepare a geological map of the entire peninsula by simply transferring the results of geological research previously conducted in the former Italian States onto the new topographic map published by military surveyors.

On 1 January, 1867 - while Cordova was still in power - a circular letter was sent to all the Prefects (representatives of the Central Government) asking for copies of all published or manuscript maps and memoirs relating to the geology of the provinces under their authority. Many never bothered to answer; others did not take the letter seriously. Given the presence of Cocchi in town, the response from the Prefect of Florence was almost comic: he stated that he was not aware of any geological work undertaken in the

${ }^{12}$ Even a cautious and apologetic historian of the Geological Survey, Alfredo Jacobacci, recognized that legislation was often of little significance to the actual workings of the Geological Office (Jacobacci 1989), a point Bruno Martinis reiterated in his 1985 manuscript white paper, Il Servizio Geologico d'Italia, now at the Archivio del Servizio Geologico, http://www.hstl.crhst.cnrs.fr/i-corpus/histmap/. 
capital of the Kingdom. At the end of a painful and frantic couple of months, by March 1867 it was abundantly clear that almost nothing was available concerning the southern half of the Peninsula; so the map sent to Paris late that summer, on the scale of $1: 1,000,000$, proved rather embarrassing. It is not even clear how long the map was actually exhibited, as it reached Paris well after the opening of the Exhibition. Giordano and Axerio insisted to Cocchi that they had done their best to have it displayed, but in August 1867 the map was still in its packaging. One wonders how much the two friends really insisted that the Commissioner of the Italian delegation display the only comprehensive geological map of North and Central Italy then available. ${ }^{13}$

By using the network of local notables, and the ready access to the Ministry of Agriculture, which was located in Florence until early 1871, Cocchi managed to survive until 1873, amidst enormous economic, scientific, and political difficulties. Finances were allocated in line with economies made by the Ministry in the previous year's budget. With few exceptions, this was the case until the early 1920s. Fellow geologists were reluctant to collaborate, and at times opposed Cocchi's leadership by refusing to attend Geological Committee meetings or to send information, specimens, or maps. ${ }^{14}$ Likewise, the officers of the Corps of Mining Engineers did their best to undermine Cocchi's authority with his staff, and to interfere with the work of the Geological Committee. ${ }^{15}$ At the political level, Sella was opposed to Tuscan geologists for their dislike of State intervention in mining matters. He also agreed with his friend Giovanni Capellini (18331922), an ambitious professor of geology at Bologna and disgruntled pupil of the Pisa school of geology, that Cocchi was a bad geologist and an even worse administrator. To prove the point, Sella waged subtle guerrilla warfare against Cocchi. While Cocchi knew something of geology, he knew little of politics, even though he tried to keep Sella happy by paying for the summer excursions of Piedmontese geologists patronized by the politician, Gastaldi in particular. Late in 1872, with his political career near its end, Sella forced the issue. He convinced Stefano Castagnola (1825-1891), the Minister of Agriculture, that Cocchi had to fully finance the geological map of Piedmont undertaken by their common friend Gastaldi, even at the cost of exhausting the Geological Committee's meagre finances. Cocchi resisted, writing memoranda and pleading against this serious interference with his work - but to no avail. ${ }^{16}$

13 Archivio Cocchi, F. Giordano to I. Cocchi, Namour, 4 August 1867: "As far as the geological map is concerned, when I was going through Paris I recommended it to the Office of the Commissioner, and pleaded that it should be exhibited in a convenient location. Since Axerio had also come to Paris to see the Exhibition, I asked him to take care of it. I stayed in Paris only a few hours, and did not have the time even to take the map out of its wrappings. Axerio, with whom I am now travelling, tells me that when he left Paris the map had not yet been exhibited, since the Commissioner had not given his permission, because the map had been received too late."

14 Archivio Meneghini, I. Cocchi to G. Meneghini. Letters covering the years 1865-1873 show that Cocchi did not get much support even from his Pisa mentor.

15 Archivio del Servizio Geologico. See for instance A. Alessandri to P. Zezi, 17 August, 1871, 12 January, 1872, 29 January, 1872. F. Giordano a P. Zezi, 12 January, 1872, at http://www.hstl.crhst.cnrs.fr/i-corpus/ histmap/.

16 Archivio del Servizio Geologico, S. Castagnola to I. Cocchi, July 24, 1872, at http://www.hstl.crhst.cnrs.fr/ i-corpus/histmap/. Archivio Centrale dello Stato, MAIC, IV Versamento, 531, envelope 258, I. Cocchi to S. Castagnola, October 29, 1872, Risposta ad alcuni quesiti riguardanti il Servizio del Comitato. Castagnola wrote on the margin off. 1r: "In view of the attitude of the Geological Committee, or at least of its President, to become exceedingly independent, by denying even to the Minister the faculty of allocating the budget .. . I invite the Inspector of the Mining Corps to study the way to organize the Committee in Rome." 
The Geological Survey was transferred to Rome, the new capital of Italy since September 1870, and Cocchi was removed from the headship of the Geological Committee. A Decree signed on 15 June, 1873 deprived the Geological Office of all independence, structuring it as a department of the Corps of Mines, exclusively staffed by engineers and under the scientific supervision of a purely consultative Geological Committee nominated by the Minister of Agriculture. The adopted map-scale was changed from 1:50,000 to 1:100,000. In the early summer of 1873 the Minister ordered that the Geological Office be established in Rome without further delay. Yet no space was available to lodge staff, books, collections, or maps, and no provision was made to help the staff meet the expenses of moving to the capital. In the end, the move took over a year to complete, much to the frustration of the staff, who were left worrying about their future. Indeed, some staff members were not prepared to accept a subordinate status to the mining engineers, and consequently left the service (at least temporarily). ${ }^{17}$

Cocchi's critics kept insisting that he was an amateur geologist who should never have been given the job, despite his chair (a junior one, it should be said) at the newly constituted University of Florence. Moreover, in the eyes of Piedmontese mining engineers, a Professor of Palaeontology like Cocchi was the least suitable candidate for understanding the technical requirements of map-making. Yet it was Cocchi who started the Survey's Library, the Bullettino del Regio Ufficio Geologico d'Italia, and its Memorie. Through the exchange of the Bulletin and the Memoirs, the Library was rapidly building up its collections, thus allowing Italian geologists to get a good view of activities in their discipline throughout the world. Cocchi also recruited the first three surveying geologists (documents relating to the first and second entrance examination are available at the Archivio del Servizio Geologico), who were duly sent to London and Liège for training. However, no major fieldwork was undertaken during Cocchi's tenure at the head of the Geological Committee. All Cocchi could afford was a trip to Elba Island for a few weeks to assess reserves of ferrous minerals, a survey of the Gottardo railway tunnel (under the supervision of Giordano), the rather uncertain beginning of the survey of Sicily and a few excursions to the outskirts of Florence. ${ }^{18} \mathrm{He}$ also acquired a considerable number of geographical and local geological maps, in order to compensate for the disastrous lack of modern topographic maps of the Peninsula, which were being slowly surveyed by the military, beginning in the still little-known South of the peninsula. No one suggested the possibility that the geological survey could go hand in hand with the topographic one.

17 Archivio Meneghini, B. Lotti to G. Meneghini, 16 March 1873, f. 1r : "we have been almost completely idle.” B. Lotti to G. Meneghini, 17 March, 1874, “At long last, I have managed to quit the Geological Committee where, following the reforms introduced by the Decree of 15 June, 1873, no other position was open to us field geologists, but to become at most assistants [engineers] of $2^{\mathrm{d}}$ class. The alternative was to agree to complete our studies abroad, which only one of us has agreed to do." The geologist who had agreed to train at the Geological Survey of London was Luigi Baldacci.

18 Zezi, 1876,pp. 9-20. Zezi had access to the archives of the Geological Committee, and his account of events is dull but rather accurate. It will remain for several decades one major source of information on the early history of the Survey. However, he does not mention his own role in the internal politics of the Committee or its relationship with the Ministry and Giordano in particular. 


\section{ALL POWER TO THE ENGINEERS: FELICE GIORDANO'S ERA}

Cocchi suspected that Sella wanted to get back the Directorship of the Survey and in the early months of 1874 rumours spread that supported his suspicion. ${ }^{19}$ In April 1874, a conference of geologists, modelled on the one held in Florence in 1861, was convened in Rome to discuss the series of terrains and chromatic scale to be adopted, as well as the organization of the renewed Geological Office. Sella played the lion, seconded by his lifelong friend Axerio. Earlier on, he had relied on Giordano, who did not take part in the April 1874 geological congress, being engaged in a politico-scientific maritime expedition. Giordano had trained at the École des Mines together with Sella, and had worked for several years in Sardinia, where he coordinated foreign private investments and State interest in the development of the backward island. In 1867 he was assigned to the Geological Committee established by Cocchi as the official representative of the Corps of Mining Engineers. Cocchi never suspected that Giordano, as Sella's right-hand man, was active in undermining the work of the Committee. The nomination to the Presidency of the Accademia dei Lincei provided Sella with a far more ambitious task: to restore Italy's place within world science, by reviving a seventeenth-century scientific academy that boasted Galileo Galilei among its members. The Geological Survey, placed in the less than capable hands of Pietro Zezi, barely survived, with finances only sufficient to pay a handful of salaries. Cocchi retreated in bitter, uncooperative silence, though he did not give up his seat in the new Comitato Geologico. For many years, his rare interventions to Committee meetings were devoted to extolling the work he had done during his tenure of the Presidency.

Due to a lack of documents, it is impossible to understand why Sella and the Corps of Mines cared so little for the Geological Survey from 1874 to 1876, particularly following all their criticism lodged against Cocchi's alleged inertia. ${ }^{20}$ It is possible that Giordano had already been selected as the future Head of the Survey, and his powerful political patron was only waiting his return from a journey in search of potential new colonies in the Far East. Back in Italy, Giordano was immediately placed in charge of the Survey, and took revenge on academic geologists whom Cocchi had unsuccessfully tried to involve in the Survey. New regulations reiterated the provision of the June 1873 decree,

19 Archivio Meneghini, I. Cocchi to G. Meneghini, 23 March 1867, 1r: "The veto comes from the Piedemontese camarilla headed by N W [Sella was coming fom the North West of the country] (intelligenti pauca); it seems that he is planning to keep it [the Directorship] warm for himself, for when the time comes." In 1874, Sella out of office, it was again reported that he was going to be put in charge of the Survey. Sella denied these rumours, Archivio del Servizio geologico, letter to Giovanni Omboni, 19 June 1874, though Omboni (1829-1910), a very active geologist from Padova, took it for granted. At the meeting in Rome in April 1874, Sella was in charge of all sessions. See Archivio del Servizio Geologico, Congresso dei Geologi Italiani tenutosi in Roma nei giorni 22, 23, 24 e 25 aprile 1874, three sets of minutes, ff. 1- 10, 1-10, 1-10. For an accurate summary of the Rome congress, see Zezi 1876, pp. 25-33. Zezi had actually drawn the minutes of the congress' sessions. Letters covering the year 1874 and preserved in the section of the Archivio del Servizio Geologico emerged at the APAT Library in December 2006, and these confirm that Sella was widely supposed to take up the headship of the Geological Survey.

20 Zezi 1876 rightly points out that lack of personnel, adequate office space and finances hampered the work of the Geological Survey. It is however possible that Prime Minister Marco Minghetti (1818-1886), who was not prepared to finance the Geological Survey on order to implement tough budget savings, offered Sella the Presidency of the Accademia dei Lincei as a suitable compensation. Equally to be considered are the first manifestations of Sella's deteriorating health. 
which stated that all surveying officers had to be engineers of the Corps of Mines. No position was anticipated for a palaeontologist in the Survey. Indeed, students from science or natural history faculties were excluded even from taking part in the rare recruitment examinations held during the late 1870 s and the 1880 s.

Behind the scenes, Giovanni Capellini became the scientific and political head of the Survey. Already in 1861, when he drafted the final report of the Florence geological conference, he hinted that the task of running the Survey was well suited to his boundless energy and superior intellectual capacities. ${ }^{21}$ Over the years, his tireless networking at national and international levels significantly constrained his scientific output, but vastly increased his influence. He organized the highly successful 1871 International Congress of Anthropology and Prehistoric Archaeology, held in Bologna. His relentless canvassing of the Royal family - he had briefly been a tutor to Prince Umberto, who obligingly opened the Congress - allowed him to get an important financial contribution from the Government. It was also thanks to Capellini that the Second International Geological Congress was held in Bologna in 1881 (Vai 2002). But it was because of Giordano and Sella that Capellini received the financial help required: his own Museum, collections, and reputation profited hugely from the event.

Still, finances for the Geological Survey remained scarce and uncertain. Thanks to Sella and to MAIC Minister Bernardino Grimaldi(1839-1897) they increased considerably during the early and mid-1880s, ultimately rising to what was still a barely sufficient operational level, but only for a period of three years. ${ }^{22}$ It was during the 1880 s that much of the first wave of large-scale field surveying was conducted, and that the Geological Office became a respected school for high quality field geologists. Luigi Baldacci (1850 1927) [Examples of whose field sketches can be seen in Figures 4-5], Domenico Zaccagna (1851-1940), Bernardino Lotti (1847-1933), Giovanni Aichino (1860-1942), Emilio Cortese (1856-1936), and Vittorio Novarese (1861-1948) - most of whom had trained at the Geological Survey of London-made extensive summer explorations of the Peninsula, though they remained unpublished for a long time (Baldacci 1911, p. 146). Publication of the map proceeded slowly, and was marred by technical, institutional, and scientific difficulties. Giordano discovered the hard truth that publishing a map required a good printer, and there were none in Italy capable of competing with German, British, or French firms. Giordano well knew that he could not obtain personnel to perform the hand-colouring of maps, as was the practice at the Geological Survey of England and elsewhere. However, in his dealings with the Ministry and Parliament, he could and did argue that the publication of the maps already completed was a task that could not be delayed any longer, and initially obtained the financial means to proceed with the printing. Thus it was financially important to sustain at least one printer capable of providing the required level of quality. Yet the Director General of the Ministry of Agriculture, Nicola Miraglia (1835-1926), grew increasingly tired of paying for endless corrections to maps which were never ready to go to press. He ultimately imposed bureaucratic rules intended to select the cheapest available printer. This proved disastrous, forcing Giordano to engage in a daily battle with the administration. ${ }^{23}$ At the same time,

${ }^{21}$ Archivio Paolo Savi, Biblioteca Universitaria di Pisa, letters from Paolo Savi to Giuseppe Meneghini covering the years $1862-1865$.

22 Bernardino Grimaldi was Minister of Agriculture from March 30, 1884 to April 1887, in three successive cabinets headed by Agostino de Pretis (1813-1887).

23 Archivio Centrale dello Stato, MAIC, V versamento busta 531 fasc. 258. 


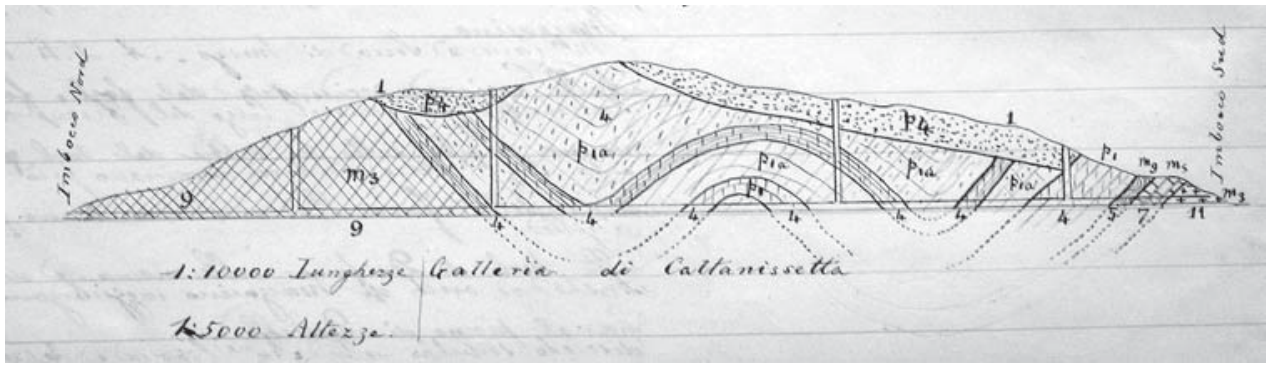

Figure 4. Luigi Baldacci and Ludovico Mazzetti, Descrizione geologica della zona solfifera di Sicilia. Fogli di Girgenti, Caltanisetta, Piazza Armerina, Palma e Licata, Archivio Del Servizio Geologico, Rome, 1878, f. 78

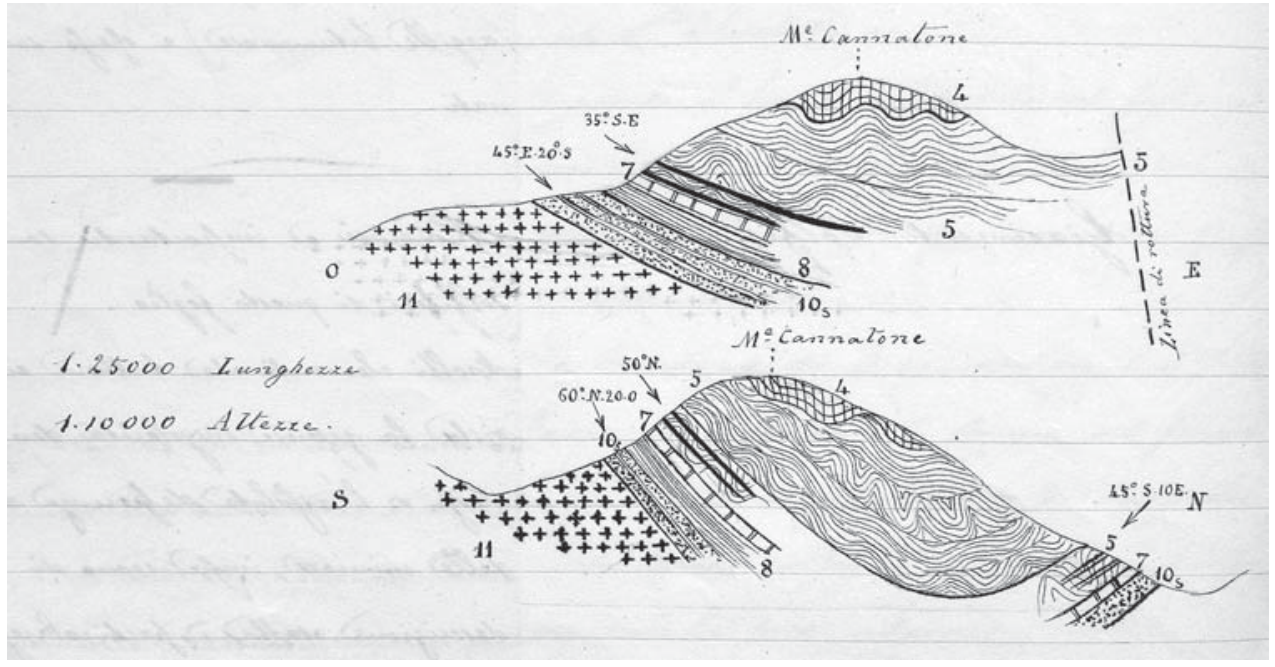

Figure 5. Luigi Baldacci and Ludovico Mazzetti, Descrizione geologica della zona solfifera di Sicilia. Fogli di Girgenti, Caltanisetta, Piazza Armerina, Palma e Licata, Archivio Del Servizio Geologico, Rome, 1878, f. 62

delays and a sluggish publication rate lent support to the protest of academic geologists, who denounced the scientific shortcomings and bureaucratic inefficiency of the State Geological Survey. Luckily for Giordano, the academic geologists were divided amongst themselves, as proven by the early history of the Geological Society of Italy. ${ }^{24}$

By the late 1880s Nicola Miraglia, the then Director General of the Ministry of Agriculture, obtained a substantial reduction in the Survey's budget from Parliament, thus allowing him to favour his own project of a hydrogeologic map of Italy. In his mind, even engineer/geologists were too theoretical to be trusted. The country needed to improve the infrastructure of agriculture, and agricultural interests ruled Parliament and politics. An almost superfluous geological map of a country that did not possess mines worthy of exploitation was a luxury to be reserved for better financial times. Bitter and isolated, Giordano died late in the summer of 1892, during a holiday at the same hotel where Miraglia was staying: this was his last attempt to mollify Miraglia and to save the project of a modern geological map of Italy that he had followed since its inception.

24 The Society was established after the 1881 International Geological Congress held in Bologna (Tellini 1892). 
The few commentators on the history of the Italian geological survey have called the $1880 \mathrm{~s}$ 'the golden age' of a less than glorious undertaking. But official papers and private correspondences cast serious doubt on this elegiac interpretation. It is true that surveying activities progressed in earnest and that personnel were well trained and productive. Yet Giordano was often left alone to ward off belligerent university geologists such as Antonio Stoppani, Torquato Taramelli, or Carlo de Stefani, who insisted that a national Geological Institute, based on the Austrian model, was the only solution to years of inertia and bad maps (De Stefani 1880, 1882, 1891, 1893, 1918; Stoppani and Taramelli 1880; Taramelli 1881). In 1882-1883 it looked as if Parliament and the Government were prepared to follow the advice of the enemies of the Geological Office. Giordano was deeply humiliated to learn that even his lifelong friend Sella agreed with Stoppani - the most vehement critic of the mining engineers running the Survey. Sella wished to appoint Giacinto Berruti (1837-1904), one of his collaborators and protégés, as Director of the soon-to-be-established Geological Institute. The relationship between Giordano and Sella remained strained until the death of the latter in 1884. From 1882 to 1884 Giordano had to rely on Capellini to get Sella to help the Survey in Parliament and with the Government. ${ }^{25}$

If Miraglia and the Ministry belatedly supported Giordano against Stoppani, and the Geological Institute's project was simply brushed aside for financial reasons, Miraglia made Giordano's life very difficult indeed. A man of inexorable energy and will, Miraglia supervised and sharply criticized every move made by Giordano, entered into the detail of every action undertaken by the Survey, and required justification for every trip, excursion or meeting involving the surveying personnel. He opposed the participation of Italian State geologists in international congresses, and refused to raise salaries or adjust the reimbursement of field-trip expenses to the cost of living. He made life impossible for Mario Canavari, the Survey's part-time palaeontologist from 1882 to 1889, who was on a yearly contract barely sufficient for survival. ${ }^{26}$ When Canavari finally opted for the Chair of Geology at Pisa upon the death of Meneghini, Miraglia revenged himself on Giordano, prohibiting the publication of any of Canavari's work in the Survey's publications. A dignified and moving letter from Giordano in 1888 tendering his resignation sums up the story of scientific, administrative and personal harassment he suffered at the hands of Miraglia. ${ }^{27}$ Fearing a scandal, Miraglia obtained for Giordano one of the highest honours the King of Italy could bestow on a commoner. Nevertheless, he did little to assist Giordano professionally, and condemned the Survey to total dependence on the Ministry accounting office and consequent daily, inimical scrutiny.

\section{DECADES OF UNCERTAINTY AND HOPE, 1892-1934}

Giuseppe Meneghini, responsible for nominally running the Geological Committee from 1879 until his death in 1889, was succeeded by Giovanni Capellini. Capellini had aspired to the job since the 1861 geological Congress in Florence. Yet, by 1889 he no longer considered geology his primary scientific or social concern: high university politics, well-paid consultancies and aristocratic obligations took up much of his time. He limited his action on behalf of the Survey to earnest, albeit unsuccessful, protestations

${ }^{25}$ Fondo Capellini, letters from F. Giordano to G. Capellini.

26 Archivio Centrale dello Stato, MAIC IV versamento, 428 A, folder "Mario Canavari".

27 Archivio Centrale dello Stato, MAIC IV versamento, 428 A, folder "Felice Giordano". 
against diminishing finances. His relationship with Giordano deteriorated, since it was clear that Giordano would not relinquish the little control over operations that the Ministry was leaving him. After Giordano's death, Capellini tried in vain to influence the running of the Survey. His conservative political instincts and allegiances did not win him a favourable ear with the liberal governments of the last quarter of the century. Moreover, the death in 1900 of his oftentimes reluctant patron, King Umberto I, further diminished Capellini's capacity to lobby the Ministry and Government successfully. He only succeeded in convincing them that the sheets already surveyed and drawn should be published. After a period of stagnation following the death of Giordano, publications resumed, though at a snail pace.

Capellini resigned his Presidency in 1912. He had been the longest-serving member of the Geological Survey of Italy, and probably of any geological Survey

But by the end of his tenure, he had squarely sided with the Survey's critics, and joined academic geologists in demanding radical reform of the Geological Office. Mining engineer geologists were rarely employed in surveying activities, as they were frequently solicited to answer urgent calls of the military, the railway administration, municipalities in need of water, and provinces devastated by landslides, earthquakes, and volcanoes (Capellini 1911). Indeed, surveying the Peninsula had virtually become a side job for the geologists employed by the Corps of Mines. Then World War I completely froze activities, as most of the geologists were called to help with the War effort. Surveying slowly resumed in the late $1910 \mathrm{~s}$, as the generation of surveying geologists recruited in the 1860 s and the 1870 s retired, and new personnel took their place. The idealistic, albeit frustrated impetus of the original grand project for a Geological Map of the Kingdom only survived in the ambitions of a handful of officers at the Corps of Mines and within academic circles, who were still fighting to get their students into the Survey and to acquiring finances for their own research, on the condition that the project was resumed.

The old guard of engineers (Baldacci and Aichino in particular) continued to defend the honour of the Corps, albeit with decreasing conviction. The engineers had justified their monopoly on the Survey by claiming that the academic geologists were wasting time in useless and unending theoretical disputes. In addition, the engineers claimed that the geologists knew little of cartography and geodesy, and devoted only a very limited part of their time to surveying, as they were so busy with their university duties. Each point was now taken up by academic geologists to fight the engineers. The academics argued that State surveying personnel maintained bitter internal warfare on the definition of strata, to the point that the already slow publication rate was made even slower by theoretical disputes, lasting at times for one decade or more. Likewise, they argued that the surveying personnel knew little of palaeontology, and were prone to frequent mistakes; the state of their collections at the head-office in Rome was deplorable; they lacked draughtsmen, chemists and petrologists; their staff was reduced to a handful of uncommitted engineers and their time was devoted to all sorts of tasks but the survey, in order to compensate for their meagre salaries, the lowest within the mining administration. There was only one solution: the Geological Office should be made completely independent from the Corps of Mines, and put under the direct authority of the Minister of Agriculture. The Geological Committee, composed of academic geologists, should exercise all power over surveying campaigns, publications, and budget allocations. ${ }^{28}$

28 See for instance De Stefani 1882, 1893 and 1918. De Stefani was the most outspoken and relentless critic of the Geological Survey. His views were shared by such geologists as Stoppani, Taramelli, Cermenati and finally Capellini. 
All hopes concentrated on the energetic amateur geologist, radical patriot politician and erudite humanist Mario Cermenati(1868-1924), who was President of the Geological Committee from 1918 to his death. Cermenati, a First World War hero and a man of considerable culture, even enlisted the support of the flamboyant poet Gabriele D'Annunzio in 1918 to underline the need for aerial photography in geological surveying. He had been a pupil and a friend of Antonio Stoppani, the earliest critic of the Geological Office. Cermenati's frequent interventions on the floor of the Lower House called attention to the 'shameful' budget allocated to the survey, and Parliament's consistent neglect of geology (Cermenati 1909). His patriotic credentials, and his constant efforts to promote (or extol) the genius of Italian science (it was Cermenati who began an important collection of studies devoted to Leonardo da Vinci) found a favourable audience within ultranationalist government circles. In 1918 Cermenati started the journal La Miniera Italiana, powerfully advocating the need fully to survey and exploit the country's mineral ressources: the First World War had shown to what a dangerous extent Italy relied on foreign supplies, due to neglect of national richness. The journal took up the cause of the reform of the Geological Survey and mobilized support within Parliament and the mining community in favour of the Survey. The Fascist Minister of National Economy, under whom the Geological Survey was placed, began attending the annual meetings of the Geological Committee. Cermenati's reforms were eventually enforced, and young university researchers began collaborating with the State Geological Survey. At last the future looked promising if not bright. ${ }^{29}$

But Cermenati's sudden death in October 1924 created short-term havoc. In due course, it led to the resignation of all of the members of the Geological Committee in 1926, who were unhappy about the lack of action following so many promises. The Geological Survey also suffered from the wave of changes required by the Fascist government. When work resumed again in 1927, the substance of the changes Cermenati had proposed were finally implemented. Federico Sacco (1864-1948), a dynamic Professor at the Polytechnic Institute of Turin, became the chair of the Geological Committee, thereby taking charge of all operations. The academic geologists savoured their victory, and embarked upon an ambitious plan of increasing surveys and publications. University professors and their assistants were summoned to help with fieldwork and the revision of maps that had remained unpublished and in storage for up to twenty years.

After 1927 the pace of publications increased, peaking in 1934, only to decline rapidly once more. Despite the paucity of available documents, we are still able to sketch the main story lines. Mining engineers continued to oppose the new arrangements in every possible way. As they could not complain about the Survey's new lease of life, they instead questioned the reliability of the maps produced, in a crescendo of explicit criticism levelled against Federico Sacco that culminated with a stormy Geological Committee meeting in November 1933. The Director General of the Ministry (alerted by Aichino, the Director of the Geological Survey, working behind the scene to undermine Sacco's credibility) told the Committee that the Minister wished to know whether claims were true that the speedy publication of the maps had come at the expense of precision. It was even reported to the Minister that the Committee was already planning a second edition of the published maps, thus explaining the lack of care, cohesion and reliability

29 See Bollettino del Regio Comitato Geologico, Parte Ufficiale, 1909-1927, Minutes of the meetings of the Geological Committee. The minutes of all the meetings of the Geological Committee, 1878-1927, are available in word format at the address http://www.hstl.crhst.cnrs.fr/i-corpus/histmap/ 
of recent maps, which were then viewed as preliminary. It was important to enquire whether proper procedures were in place in order to ensure that mistakes or questionable strata identifications did not reach the printing stage. ${ }^{30}$

Somewhat embarrassed, Committee members, out of respect for Sacco's role as President of the Geological Committee avowed that his maps had never been submitted to peer-review scrutiny. The surviving minutes appear to substantiate the hypothesis that at least one member of the Committee, Giovanni D'Achiardi (son of Antonio, Meneghini's right hand at Pisa, 1872-1944), sided with the engineers against Sacco. The surprise factor and divisions among academic geologists allowed the representative of the Ministry and the Director of the Survey successfully to move that the university professors of geology sitting in the Geological Committee should from now on abstain from surveying and publishing activities. It was furthermore decided not to publicize the discussions held, in order to avoid discrediting Sacco and the entire Committee. The little money allocated to the Survey should be put at the exclusive disposal of the mining engineers serving as field geologists. Sacco remained the nominal President of the Committee until his death in 1943. It is significant that only one obituary was published in the Italian scientific press. The Bollettino del Servizio Geologico did not regret nor even mentioned the loss of the President of the Geological Committee. In May 1943, the Geological Committee was abolished, and subsequently replaced by a consultative Geological Commission, which was appointed and chaired by the Head of the Geological Survey. Academic geologists were once against out, and the mining engineers regained control over operations. Yet funding for the Survey almost disappeared, and engineer-geologists returned to their routine work for a variety of State administrations and agencies. Neither the academics nor the engineers - let alone the country - gained from the situation.

\section{WAR AND RECONSTRUCTION: THE GOLDEN DECADE AND ITS AFTERMATH}

Already after the death of Cermenati, finances were again on the decline, and subjected to the erratic political decisions of an embattled and isolated Fascist regime. When one year it appeared as if the Geological Committee could solve Italy's oil and coal supply issues, extra money was duly provided. A year later, private companies were asked to drill (at the cost of one million liras per drill, as opposed to the 100,000 liras allotted annually for the entire operation of the Geological Survey) in areas which the Committee had repeatedly declared barren of any fossil fuel resource. Budget allocations for the geological map declined to irrelevance. But new private and State agencies appeared, which were better suited to solve problems within months, instead of decades. After all, many argued, the Italian State had funded the Geological Map project since 1861, and nothing tangible had come out of it. In the end, Italy did not find an oil field, failing even to discover the black gold in Libya (in spite of local Italian engineers alerting the central Geological Office of its probable large-scale presence there), and was still without a

30 Archivio del Servizio Geologico, Minutes of the meeting of the Geological Committee, 11-12 November, 1933. The representative of the Minister put forth four questions: "1) Is it true that surveying methods have been changed in order to increase speed?; 2) Has speed decreased the accuracy of surveying campaigns?; 3 ) Is the decrease in accuracy damaging the scientific and practical outcome of the surveying work; 4) Is there any action to be taken?" 
working geological map of the country. ${ }^{31}$

Year after year, the increasingly scarce official documents so far discovered tell a story of understaffing, poor financing, marginality, and neglect. On top of these problems lay the drama and disaster of the War, the civil war of 1943-1945, and the haphazard and disorganized reconstruction effort of the late 1940s and the 1950s. To some, the Geological map of the country seemed a patriotic duty of doubtful practical application - better left to more stable and prosperous times. To others, State geologists and geological maps implied State intervention, and limits unreasonably imposed on free enterprise and to the right to build villages and roads even on unstable grounds. Employment (and profit) had to be guaranteed, even at the cost of destroying natural resources and of severely endangering the integrity of the Italian landscape - or the life of its citizens. The reconstruction was savage and, as a series of disasters costing hundred of human lives kept reminding public opinion, little care was taken to ensure the security of locations chosen for building roads and houses.

During the 1950s, the ever contradictory and complex history of Italy, a country always straddling the boundary between modernity and archaism, achieved a moment of great ferment and innovation. International and national conditions favoured an unanticipated economic boom. Within the ruling government parties, there was a handful of enlightened politicians who sincerely wished to work for the future of the country. Within this movement, intellectuals led by Manlio Rossi Doria (1905-1988) and the politician Fiorentino Sullo (1921-2000) developed a crash programme to complete the Geological Map of Italy. A Geological Commission composed of a majority of university geology professors convened in June 1858. They re-constituted the Geological Committee, and rightly stressed the need to complete a project so embarrassingly delayed. The legislation passed on 3 January, 1960, known as Legge Sullo, provided finances and a solid institutional framework to survey, revise and print 140 sheets (which had never been surveyed before or were out of print) of the geological map on the scale 1:100,000. Smouldering old rivalries were dispelled with a stroke of innovative administrative engineering. A plurality of State and semi-private agencies were summoned to participate, including the universities. The staff of thirty-two State geologists was significantly increased by the temporary recruitment of scores of young surveyors who learned their trade in the field. It was a gigantic and successful effort. Yet the time lost had a price.

As the President of the Geological Committee, Ardito Desio, wrote in June 1970 to the Minister of Industry and Commerce, the completion of the Geological Map on the scale 1:100,000 did not mean that all problems were solved. On the contrary, a workable geological map, he argued, had to be published on the scale of 1:50,000 (652 sheets to cover the country) in order to be of any practical use, and the survey fieldwork had to be drawn on the scale of 1:25,000 (3,572 mapping slips). Furthermore, it would be unwise not to recruit the almost one hundred young geologists who had acquired professional maturity on the field as permanent staff. The time was ripe to enter a modern conception of governance for the State's territories. For this, a modern geological map was an indispensable precondition (Desio 1971; Martinis 1985, p. 8). But from 1970 onward,

31 Archivio del Servizio Geologico, Minutes of the meeting of the Geological Committee, December 17, 1922, "Our present knowledge of the geology of Libya is sufficient to exclude the viability of a general exploration to find oil. We do not possess information on which to authorize the drilling: the information concerning the finding of traces of oil during the drilling of a water well at the School of Agriculture in Tripoli does not justify an extensive research." 
history repeated itself. The golden decade had gone, and events showed a remarkable similarity to a century-long pattern involving lukewarm political interest, poor financing, institutional infighting, press campaigns and natural disasters periodically calling for the reform of the State geological services. In addition, competitors increased in number and prestige, successfully forcing the Geological Survey to fight for its survival.

In spite of repeated claims to the contrary, the Geological Survey of Italy never enjoyed the monopoly of geological cartography. Even during the 1880s, a time of good finances and proud reaction against academic critics, it employed the services of individual university geologists by commissioning special studies of particular areas. This was due to a variety of reasons, ranging from pressure placed on the Survey by powerful politicians to hire a few academic geologists, to the desire to pacify a tiresome critic of the Survey by buying time and allowing him to conduct his research. This was the case, for instance, with Torquato Taramelli, a follower of Garibaldi in his youth, and professor of geology at Pavia. Together with his teacher (Stoppani) during the late 1870s and the $1880 \mathrm{~s}$, Taramelli waged a sustained, and at times violent, press campaign against the Geological Survey. Through complex manoeuvres and the intercession of Quintino Sella, Taramelli was brought to see reason, his research was financed by the Survey, and he toned down his attacks.

During the 1920s, the Magistrato alle Acque (Water Authority) of Venice financed a geological and hydrogeological map of the Venetian region, under the direction of Giorgio dal Piaz (1872-1962). The project was eventually brought under the aegis of the Survey, but not without difficulties and polemical exchanges ${ }^{32}$ Moreover, the constitution of the Council for National Research (CNR) established in 1923, which enjoyed strong political support, and the charismatic leadership of Guglielmo Marconi (1874-1937) from 1927 to 1934, further marginalized the scientific profile of the Geological Survey. It was becoming increasingly clear that mining engineers active in the Geological Survey did not, and could not, take part in the theoretical debates animating the geological community during the first forty years of the twentieth century. Geology was abandoning its natural historical and mineralogical origins, and was increasingly turning towards physics as its model. The Survey tried to follow this move by hiring geophysicists, but its style of surveying work and operational priorities were not significantly changed. Mining engineers had only half-heartedly accepted the transition form lithostratigraphy to biostratigraphy. The transition to geophysics was equally lukewarm.

Traditional cartographic duties were generally used to enhance the visibility and continuation of the Geological Survey. Yet on the contrary, Marconi believed that terrestrial physics was the future for geology, and that it was too serious a matter to be left to field geologists. In 1929 the CNR established a geodetic and geophysical national committee, transformed on 15 December, 1936 into the Istituto Nazionale di Geofisica (ING, National Institute of Geophysics). It was placed under the control of Antonino Lo Surdo, a capable administrator and politician of science. He had done some work in physics during the early years of the century but was disliked by top-ranking physicists such as Enrico Fermi and Emilio Segré. Like Marconi, Lo Surdo was a strong sympathizer with Fascism and managed to steer the ING through the storm of the War. The Institute emerged from the tragedy of the civil war (1943-1945) almost unscathed, ready to profit

32 Bollettino del Regio Ufficio Geologico, Parte Ufficiale, Minutes of the meeting of the Geological Committee, 1927, p. 25. 
from the increasing importance of physics and geophysics in the cold-war decades, when physicists commanded political attention and a constant flow of financial resources.

A close reading of documents relating to the decade 1960-1970 reveals that the Geological Survey failed to play a significant role even when resources had been made available by Parliament. In the report he published in 1971 that we referred to, Desio limited himself to quoting data clearly showing that officers at the Geological Survey had completed less than one-third of the 140 sheets printed at the time. Moreover, a short biography of Ezio Beneo, the then Director of the Survey, hints that survey geologists were not entirely happy with the methodology of work and theoretical framework adopted by their academic colleagues involved in the crash programme to complete the geological map at the 1:100,000 scale. At the end of the decade 1960-1970, and throughout the 1980s, the Geological Survey was once again facing the by now chronic problems of underfinancing, understaffing and lack of institutional prestige (Jacobacci 1981, p. 313; Jacobacci 1982, p. 285; Jacobacci 1984, p. 371).

In the 1970s, when the Geological Survey was lobbying government and the press to denounce the plight of geological cartography in Italy, a series of natural disasters alerted public attention to the lack of serious research on the natural hazards likely to befall a country like Italy. The Geological Survey tried to take advantage of the situation, but it was not alone, nor the most successful.

On May 6, 1976, a major earthquake unleashed havoc in the Friuli region on the North-East of the peninsula. Almost one thousand people were killed, and residual seismic activity lasting for weeks only added to the drama. Reconstruction efforts began in earnest, and it soon became clear that no geological maps existed of the provinces affected by the seism. The geological map published by Torquato Taramelli in the late nineteenth century was no longer available, and local administrations were at a loss as to how to proceed with the reconstruction. In spite of public outcry on the state of geological mapping in Italy, it was the CNR and the ING that provided advice and help in the region affected by the earthquake. Nevertheless, the Geological Committee did alert the press and lobbied the government in an effort to highlight the economic and human cost of the lack of modern geological cartography (Martinis 1985, p. 9).

Nature struck again on November 23, 1980, in the Apennine region of central Italy called Irpinia. This time, the death toll reached 2,914, and more than 10,000 wounded required medical assistance. The Geological Survey increased its lobbying, and joined the chorus of voices from the press and opposing political parties arguing that in a country like Italy, the effects of natural disasters were magnified by decades of poor administration and a total neglect of research and geological surveying. Late in November 1980, at a press conference at the Ministry of Research, geologists and members of the press launched a powerful indictment on the responsibilities of politicians.

In the words of Bruno Martinis, the President of the Geological Committee, several participants stressed that in a country like Italy, which was subject to landslides, earthquakes and volcanic activity, the barely surviving Geological Survey was "the inevitable result of the most obnoxious lack of interest towards a meaningful territorial policy" - a lack of interest that was causing the country immense economic and human losses (Martinis 1985, p. 47).

If the two disastrous earthquakes of 1976 and 1980 contributed to the development of the National Institute of Geophysics (from 1983 under the shrewd headship of Enzo Boschi, 1942- ), a new disaster rescued the embattled and embittered Geological Survey. On 19 July, 1985, an artificial dam located in Val di Stava (in the Trentino region) 
containing $160,000 \mathrm{~m}^{3}$ of mud from a mining exploitation gave way, killing 268 people. This time, it was clear that the disaster had little to do with nature. Debates in Parliament established that the Geological Survey could not undertake inspection duties, having insufficient personnel even to handle daily routine tasks. ${ }^{33}$ Moreover, a proper, modern geological survey of the locality would have been sufficient to alert mining officers of the unsuitability of the terrain and the consequent danger posed by the dam. At the pace which surveying work and publication were proceeding, Martinis wrote in his White Paper of 1985 , the new geological map of Italy on the scale of 1:50,000 would be completed in the year 2600. Who was going to take responsibility for the many foreseeable disasters to come, he asked (Martinis 1985, p. 25)?

\section{THE PRESENT}

The account of the Geological Survey of Italy's activities in the period following World War II has been greatly assisted by the unpublished White Paper written by Bruno Martinis in 1985, as well the relevant legislation and papers in the press, particularly those regarding the furious polemics following the 'natural' disasters just alluded to. The contemporary period is difficult to assess from a critical point of view and the historian must either turn into a 'mere chronicler', or embark on enormous investigative work which no one in present-day Italy will ever finance or welcome.

A series of legislative measures enacted in the late 1980s and throughout the 1990s has provided sufficient funds to finally undertake the completion of the geological map of Italy on the scale 1:50,000. ${ }^{34}$ However, the most recent Report, published in the autumn of 2005, projecting activities through the first half of 2006, shows that only thirty-four sheets of the 257 (out of a total of 652) due to be completed during the first phase of the project have been published. If the model adopted, of implicating a vast array of partners in the project (Regional Councils, universities, the CNR, private and State agencies) is reminiscent of the decade 1960-1970, the fact that the Geological Survey has practically no authority over the work conducted at the local levels means that 'virtuous' regions like Emilia Romagna or Tuscany have progressed at a steady pace, whereas the regions most in need of sound surveying work after decades of unruly exploitation of the territory (including southern Italy) are lagging seriously behind. Local, political, and economic interests are probably at work since, for instance, the results of a modern survey might greatly diminish the value of lands which are presently open to commercial speculation, yet are geologically unsuitable for development projects. Whatever the reason, the official documents readily available leave no doubt as to the uneven and problematic progress of the 1:50,000 coverage project.

In the meantime, a succession of transfers of the Geological Survey from one ministry to the next has produced a perceptible decrease in the importance of the Geological Survey within the State hierarchy (Todisco 1988, p. 315). If until the 1980s the Director General of the Geological Survey was on a par with the other Director Generals running ministries, enjoying direct access to the Minister in charge, since

33 Law 464, promulgated on 4 August, 1984, had indeed increased the inspection powers of the Geological Survey, and charged it with collecting all sorts of information on geological risks: but did not foresee any increase in budget or personnel.

${ }^{34}$ For a summary view of laws passed by Parliament and their financial impact on the Geological Survey, see APAT, Carta Geologica d'Italia, Rapporto informativo periodico (aggiornamento maggio 2006), p. 2. 
August 2003 the Geological Survey has become far removed from power, as an Office within the Dipartimento di Difesa del Suolo (Department for the defence of the territory), a branch of the Agenzia per la Protezione dell'Ambiente e per $i$ Servizi Tecnici (Agency for the Protection of the Environment and the Technical Services). Moreover, the increased devolution of geological matters to Regional Councils has allowed the Central Government to distance itself from chronic and unresolved problems of territory governance by transferring them to other branches of the Administration, together with all political responsibility. Only the future will tell whether Italy's Geological Survey project, started in 1861, will ever be completed.

\section{CONCLUSION}

Unlike the vast majority of European and non-European countries, Italy failed to complete a single, reliable edition of its geological map. The project, began in 1862, and apparently completed in 1970, could not, in the words of those who were active in the effort from 1960 to 1970 , be considered the result of a coherent surveying effort. In other words, the finished product from 1970 does not constitute a comprehensive geological map of the national territory. Indeed, many sheets of the map on the scale 1:100,000 were out of print, or had followed disparate criteria of representation and interpretation. It is interesting to note that it was not the lack of trained personnel that hampered the effort. During the 1880s and 1890s, most of the field geologists had trained in London, Paris or Liège. Their work was generally satisfactory and at times excellent, as was the survey of the Apuane Alps conducted by Domenico Zaccagna. What was lacking was support from Parliament and successive governments. When the survey gained access to a powerful politician - however long his commitment actually lasted - work proceeded at a satisfactory pace. Quintino Sella, Bernardino Grimaldi, Mario Cermenati, and Fiorentino Sullo provided moral and financial support that lasted at times several years, during which much work was done. On the whole, localism prevailed over the national interest, as is quite often the case in the history of the Italian State. A long-term project like a geological survey would have benefited one province, or a few, in the short term. Political leaders would reasonably - from their point of view - prove reluctant to appear to be supporting surveying work on provinces outside their constituency. In 1985 Bruno Martinis reported that a then powerful politician and Prime Minister told him that he was only interested in matters concerning his hometown - shortly to be affected by a rather serious earthquake (Martinis 1985, p. 24). In other cases, a geological survey could have altered the balance of power of agrarian and land development ownership, by warning against the suitability of valleys and planes for new urban or industrial settlements.

The geological survey of Italy was also the victim of trends at an international level. The heyday of geology lasted for about fifty years throughout Europe. By the end of the nineteenth century, many national surveys had to change their strategy in order to survive. They had to prove their ability to solve pressing problems including the provision of water supplies to growing towns, sanitation, the search for fuels or raw materials, and the protection of coasts and the preservation of agricultural land from the inroads of rivers or the sea. Italian mining and geological engineers did provide answers for several of these problems, but always as consultants to other Ministries or agencies. They took part in the feasibility study and running of new railway lines, the construction of water reservoirs, and the reconstruction of cities destroyed by earthquakes (including Ischia in the early 1880s, and Messina after the earthquake and tsunami of 1909). Yet they did so, 
on the payroll and political agenda of a variety of Ministries, State agencies, and private companies. They proved unable, and unwilling to claim such functions for their Geological Office.

In order to guarantee the survival of their institution in light of the growing prestige and political power of geophysics after the Second World War, State geologists could only appeal to national pride and the primary duty of the State to preserve the life of its citizens. But once again, the surveying work and the publication of a geological map far surpassed the expectations of politicians facing elections every four years - or less, in the Italian case. Once finances were voted upon by Parliament, the lack of support guaranteeing the application of budget dispositions in concert with a Parliamentary or Ministerial control often meant that decrees and budgets were ultimately ineffective.

The Geological Office and the Geological Survey mainly survived due to political and administrative inertia. As a section of a State corps (the mining engineers), and then a department of the State, the Geological Survey was protected against obliteration but still became irrelevant. The Survey's status as a bureaucratic function of the State exempted it, at times, from being scientifically proficient, or from competing with academic or CNR geologists. However, its total dependence on the State bureaucracy and political hierarchy considerably decreased its negotiating power over the years. The present situation of the Geological Survey, relegated to a subordinate position in the decision-making process within the Agency for the Environment, is the direct result of 150 years of negligence in long-term territorial policy making, professional jealousies and in-fighting. It is also the result of public indifference, with citizens only occasionally awakened to the grave cost of not investing in a reliable geological map of the national territory.

\section{ARCHIVES}

Archivio del Servizio Geologico, Rome. This was kept at the historic central office of the Geological Survey, in Largo di Santa Susanna, Rome. Several renovations of the building have destroyed the majority of holdings. The contents of a cupboard preserving what was left were photocopied in the 1990s, although the originals are no longer available. In 2003, Roberto Volpe, a former employee of the Geological Survey, put a few folders he had managed to salvage from destruction at my disposal. These covered the early recruitment procedures, and documents relating to the period 1930-1950. All of the Geological Survey Archive's holdings which I was able to obtain or photocopy are now accessible at the Histmap website: http://www.hstl.crhst.cnrs.fr/i-corpus/histmap

In December 2006 Dr Emi Morroni, Head of Department at the Agency for the Protection of the Environment (Apat), has kindly informed me that more files of the historic Archive have been recently found in a second locked cupboard. It is important to emphasize that this newly found archive does not appear to contain all the documents photocopied during the 1990s.

Archivio Centrale dello Stato, Rome. The Central Archive of the Italian State in Rome preserves an important collection of papers relating to the daily activities of the Ministry of Agriculture, Industry and Commerce (MAIC) from the late 1850s to the early 1900s. An excellent description of these holdings can be found in Nella Eramo's Fonti per la storia della scienza e della tecnica, 1995. Of particular interest to our study are the following folders:

MAIC 4194, 1: Direzione generale agricoltura, V versamento, 951, fascicolo 4194, 1, "Fascicolo n. 1. 1860 1861. Giunta consultiva per discutere i metodi e stabilire le norme per la formazione della Carta Geologica del Regno d'Italia"

MAIC 4194, 2: Direzione generale agricoltura, V versamento, 951, fascicolo 4194, n. 2, “Fascicolo n. 2.1861. $\mathrm{Dal} 1^{\circ}$ settembre a tutto il 12 dicembre. Giunta consultiva per discutere i metodi e stabilire le norme per la formazione della Carta Geologica del Regno d'Italia"

MAIC 4194, 3: Direzione generale agricoltura, V versamento, 951, fascicolo 4194, n. 3, "Fascicolo n. 3, 1862 $=63=64$ e 1865. Giunta consultiva per discutere e stabilire le norme per la formazione della Carta 
Geologica dle Regno d'Italia"

MAIC 4194: Direzione generale agricoltura, V versamento, 951, fascicolo 4194, “Contabilità. 1861. Giunta consultiva per la formazione della Carta Geologica del Regno d'Italia"

Archivio Capellini, Bologna The more than 20,000 letters of the Giovanni Capellini archive, which are preserved in the Biblioteca dell'Istituto in Bologna, detail Capellini's involvement with the science and politics of the Geological Survey from 1860 to 1912.

Archivio Cocchi. Private. The correspondence of Igino Cocchi, founder of the Geological Committee in charge of the Geological Survey of Italy from 1867 to 1873, has been patiently rescued by Mr. Fausto Barbagli of the Museo di Storia Naturale in Florence. It is comprised of several hundred letters. Of particular importance is the exchange of letters between Cocchi, Giuseppe Meneghini and Felice Giordano.

Archivio Meneghini, University of Pisa. Almost abandoned in a loft of the Department of Earth Sciences at the University of Pisa, Giuseppe Meneghini's correspondence and archives are invaluable for the reconstruction of the early history of the Geological Survey. Several hundred letters from Igino Cocchi to Giuseppe Meneghini are complemented by the Archivio Cocchi which Mr Fausto Barbagli has assembled. The Meneghini Archive in Pisa is undergoing yearly deterioration due to lack of facilities and minimal funding to proceed to a proper storing and cataloguing.

Archivio Savi, Biblioteca Universitaria, Pisa. The University Library at Pisa preserves the rich Leopoldo Pilla archive, which along with the correspondence of Paolo Savi remains unexplored. Of particular interest are the letters exchanged between Giuseppe Meneghini and Paolo Savi. An important collection of Paolo Savi's scientific papers is also preserved, albeit precariously, at the Dipartimento di Scienze della Terra, Pisa University.

Archivio Sella, Biella. The Fondazione Sella in Biella preserves the important archive of Quintino Sella. This correspondence is also of great importance to the understanding of the Geological Survey's early history. This archive is complemented by the Archivio Centrale dello State holdings, which monitors Sella's early activity as the first Director of the Italian Survey.

Archivio Zaccagna, Carrara. The Istituto di Belle Arti di Carrara holds the personal archive and correspondence of Domenico Zaccagna, a colourful field operator active in the Italian Geological Survey from the late 1870s until well after his retirement in the late 1910s. The daily work of a field operator - albeit a very independent one - can be traced through field notes, manuscript memoirs, petitions and personal papers.

\section{REFERENCES}

Anon. 1940. Cenni biografici e bibliografici sull'opera del personale dell'Ufficio Geologico dalla sua fondazione al 1940. Bollettino del R. Ufficio Geologico d'Italia 65: 13-18.

Atti I. 1840. Atti della prima riunione degli scienziati italiani tenuta in Pisa nell'ottobre del 1839, $2^{\mathrm{d}}$ ed. Pisa: Tipografia Nistri.

Atti II. 11841. Atti della seconda riunione degli scienziati italiani tenuta in Torino nel Settembre del 1840. Turin: Tipografia Cassone and Marzorati.

Atti III. 1841. Atti della terza riunione degli scienziati italiani tenuta in Firenze nel settembre del 1841. Florence: Coi Tipi della Galileiana.

Atti IV. 1843. Atti della quarta riunione degli scienziati italiani tenuta in Padova nel settembre del 1842. Padoua: co' tipi del Seminario.

Atti V. 1844. Atti della quinta riunione degli scienziati italiani, tenuta in Lucca nel settembre del 1843. Lucca: Tipografia Giusti.

Atti VI. 1845. Atti della sesta riunione degli scienziati italiani: tenuta in Milano nel settembre del 1844. Milan: Luigi Di Giacomo Pirola.

Baldacci, Luigi 1911. La Carta Geologica d'Italia. Rome: Tipografia della Società Editrice Laziale. Originally printed in Bollettino del Regio Comitato Geologico, 1911, V series, vol. 2, part 2: 99-169.

Barsanti, Giulio, Becagli, Vieri and Pasta, Renato (eds.) 1996. La politica della scienza. Toscana e Stati Italiani nel tardo Settecento. Florence: Leo S. Olschki.

Butcher, J. V. Norman E. 1983. The Advent of Colour-Printing Geological Maps in Britain, Proceedings of the Royal Institution of Great Britain 55:149-161.

Capellini, Giovanni 1911. Discorso del Sen Capellini in commemorazione del L anniversario della Carta Geologica d'Italia. Bollettino della Società Geologica Italiana 30: 175-193.

Carneiro, Ana 2005. Outside Government Science, 'Not a Single Tiny Bone to Cheer Us Up!' The Geological Survey of Portugal (1857-1908), the Involvement of Common Men, and the Reaction of Civil Society 
to Geological Research, Annals of Science 62: 141-204.

Carusone, Angela, Morroni Emi, Zanfrà Silvana (eds.) 1996. La Carta geologica d'Italia. Un itinerario bibliografico. Rome: Presidenza del Consiglio dei Ministri, Dipartimento per i Servizi Tecnici Nazionali, Biblioteca, Istituto Poligrafico e Zecca dello Stato.

Cermenati, Mario 1891. Il R. Comitato Geologico d'Italia. Brevi cenni di cronaca. Rome: Tipografia della Società Laziale. Originally published in 1891, in Rassegna delle Scienze Geologiche in Italia 1: 448463.

Cermenati, Mario 1909. Discorso del Deputato Prof. Mario Cermenati discutendo il bilancio di Agricoltura, Industria e Commercio nella tornata del 14 maggio 1909. Lecco: Cooperativa Lecchese.

Cermenati, Mario 1918. Per la Carta Geologica d'Italia. Oltre mezzo secolo di voti, di proposte, di decreti, di riforme invocate. La Miniera d'Italia 2: 361-367.

Clerici, Enrico 1933. Bernardino Lotti. Bollettino della Società geologica italiana 52: cxliii-clv.

Cocchi, Igino 1871. Brevi cenni sui principali Istituti e Comitati Geologici e sul R. Comtato Geologico d'Italia per servire di introduzione al I volume delle Memorie, Memorie del R. Comitato Geologico d'Italia 1: 3-33.

Cook, Karen S. 1995. From False Starts to Firm Beginnings: Early Colour Printing of Geological Maps. Imago Mundi 47: 155-172.

Cordova, Vincenzo 1889-1893. Filippo Cordova : $i$ discorsi parlamentari e gli scritti editi ed inediti preceduti dai ricordi della sua vita. 4 vols Rome: Forzani.

Corsi, Pietro 1982. Cocchi, Igino. Dizionario biografico degli italiani 26: 473-476.

Corsi, Pietro 1991. De Stefani, Carlo. Dizionario Biografico degli Italiani 39: 438-442.

Corsi, Pietro 1995. The Pisa School of Geology of the 19th Century: an Exercise in Interpretation. Palaeontographia Italica 82: iii-viii.

Corsi, Pietro 1998. Le scienze naturali in Italia prima e dopo l'Unità. In Ricerca e istituzioni scientifiche in Italia, Raffaella Simili (ed.), 28-42. Bari: Laterza.

Corsi, Pietro 1999. Gemmellaro, Carlo. Dizionario biografico degli italiani 53: 59-62.

Corsi, Pietro 1999. Gemmellaro, Gaetano Giorgio, Dizionario biografico degli italiani 53: 63-64.

Corsi, Pietro 2001. La Geologia. In Storia dell'Università di Pisa. Voume. 2, tome 3, 889-927. Pise: Edizioni Plus.

Corsi, Pietro 2003a. Which instruments for Geological mapping? The Case of the Italian Geological Survey, In Musa Musaei. Studies on the History of Scientific Instruments and Collections in Honour of Mara Miniati, Marco Beretta, Paolo Galluzzi, and Carlo Triarico (eds. ), 433-442. Florence: Leo S. Olschki.

Corsi, Pietro 2003 b. How to Use Centres in the Periphery: Italian Geology in the Nineteenth Century. In Centre and Periphery Revisited. The Structure of European Science, 1750-1914, Robert Fox (ed.), special issue, Revue de la Maison Française d'Oxford, volume 1, 2: 51-67.

Corsi, Pietro 2003c. The Italian Geological Survey: the Early History of a Divided Community. In Four centuries of the word 'Geology', Ulisse Aldrovandi 1603 in Bologna, Gian Battista Vai and Walter Cavazza (eds), 255-279. Bologna: Minerva Edizioni.

Corsi, Pietro (ed.) 2004. http://www.hstl.crhst.cnrs.fr/i-corpus/histmap

Della Marmora, Alberto 1857. Voyage en Sardaigne, ou Description statistique, physique et politique de cette ile, avec des recherches sur ses productions naturelles et ses antiquités. Vol. 3, Part 1. Description géologique. Turin: Bocca; Paris: Betrand.

Desio, Ardito 1971. Parole pronunziate dal Presidente del Comitato Geologico d'Italia A. Desio nella seduta di chiusura (26 giugno 1970) dell'attività del Comitato a conclusione di un decennio di lavoro (19601970). Bollettino del Servizio Geologico d'Italia 92: 127-132.

De Stefani, Carlo 1880. Res geologicae. Siena: Tipografia dell'Ancora.

De Stefani, Carlo 1882. L'Ufficio Geologico d'Italia. A proposito del progetto di legge sulla Carta Geologica. Siena: Tipografia dell'Ancora.

De Stefani, Carlo 1891. La carta geologica d'Italia pubblicata per cura del R. Ufficio geologico nel 1889. Bollettino della Società geologica italiana 10: 92-97.

De Stefani, Carlo 1893. La carta Geologica d'Italia e lo Stato. Memoria letta alla R. Accademia dei Georgofili nell'adunanza del dì 9 luglio 189. Firenze: Tipografia di M. Ricci.

De Stefani, Carlo 1918. La geologia e la Carta Geologica. Atti della R. Accademia dei Lincei 27: $215-219$.

Ellenberger, François 1983. Recherches et réflexions sur la naissance de la cartographie géologique, en Europe et plus particulièrement en France. Histoire et nature 22-23: 3-54 
Eramo, Nella 1995. Fonti per la storia della scienza e della tecnica negli archivi del Minstero di agricoltura, industria e commercio. In Gli archivi per la storia della scienza e della tecnica 1019-1039. Rome: Ufficio centrale per i beni archivistici.

Esposizione in ordine cronologico delle principali disposizioni successivamente emanate relativamente alla Carta Geologica d'Italia, offfprint n.d., Atti della Società Italiana di Scienze Naturali (Rome, Archivio del Servizio Geologico).

Garin, Eugenio 1991. Il Congresso Pisano degli scienziati italiani del 1839. Giornale Critico della Filosofia Italiana 10: 280-292.

Giordano, Felice 1877. Cenni sul lavoro della Carta Geologica. Annali del Ministero di Agricoltura, Industria e Commercio 86: 1-22.

Giordano, Felice 1880. Resoconto sul lavoro della Carta Geologica d'Italia (principio del 1879). Rome: R. Ufficio Geologico.

Greene, Mott T. 1982. Geology in the Nineteenth Century: Changing Views of a Changing World. Ithaca and London: Cornell University Press.

Guntau, Martin 1988. The History of the Origins of the Prussian Geological Survey in Berlin, 1873. History and Technology 5: 51-58

Hallam, Anthony 1990. Great Geological Controversies. Oxford: Oxford University Press.

Herries Davies, Gordon L. 1983. Sheets of Many Colours: The Mapping of Ireland's Rocks. Dublin: The Dublin Royal Society.

Jacobacci, Alfredo 1973. Il centenario del Servizio Geologico d'Italia. Bollettino del Servizio Geologico d'Italia 94: 3-26.

Jacobacci, Alfredo 1981. Relazione sulle attività del Servizio Geologico nel 1981. Bollettino del Servizio Geologico d'Italia 102: 313-328.

Jacobacci, Alfredo 1982. Relazione sulle attività del Servizio Geologico nell'anno 1982. Bollettino del Servizio Geologico d'Italia 103: 285-310

Jacobacci, Alfredo 1984. Relazione sulle attività del Servizio Geologico nel 1983. Bollettino del Servizio Geologico d'Italia 104: 371-386.

Jacobacci, Alfredo 1989. Ricordo di Enzo Beneo. Bollettino del Servizio Geologico d'Italia 109: 241-250

Knell, Simon J. 2000. The Culture of English Geology, 1815-1851: A Science Revealed through its Collecting. Aldershot: Ashgate.

Martinelli, Alessandro 1927. Discorso pronunciato alla inaugurazione del monumento a Mario Cermenati. Bollettino della Società Geologica Italiana 46: 90-95.

Martinis, Bruno 1985. Il Servizio Geologico d'Italia. Libro Bianco. Ms., Archivio storico, Servizio Geologico at http://www.hstl.crhst.cnrs.fr/i-corpus/histmap/.

McCartney, Paul J. 1976. Charles Lyell and G. B. Brocchi: A study in comparative historiography. British Journal for the History of Science 9: 175-189.

Millosevich, Federico 1931. La carta geologica del Regno. Discorso del Senatore Federico Millosevich pronunciato nella tornata del 20 maggio 1931-IX. Rome: Tipografia del Senato.

Mori, Giorgio 1971. L'estrazione dei minerali nel Granducato di Toscana durante il periodo delle riforme (1737-1790). In Studi di storia dell'industria, Giorgio Mori (ed.), 83-141. Rome: Editori Riuniti.

Nelson, Clifford M. 1999. Toward a reliable geologic map of the United States, 1803-1893. In Surveying the Record. North American Scientific Exploration to 1930, E.C. Carter III (ed.), special issue, Memoirs of the American Philosophical Society 231: 51-74.

Neviani, Antonio 1925. Mario Cermenati. Bollettino della Società Geologica Italiana 44: 118-129.

Oldroyd, David 1996. Thinking about the Earth: A History of Ideas in Geology. London and Cambridge Mass.: Harvard University Press.

Pancaldi, Giuliano (ed.) 1983. I congressi degli scienziati italiani nell'età del positivismo. Bologna: Clueb.

Pasta, Renato 1989. Scienza politica e rivoluzione. L'opera di Giovanni Fabbroni (1752-1822) intellettuale e funzionario al servizio dei Lorena. Florence: Leo S. Olschki Editore.

Pellati, Nicola 1895. Sulla formazione e pubblicazione della Carta geologica del Regno. Rome: Stabilimento Tipografico G. Civelli.

Pellati, Nicola 1904. Contribuzione alla storia della cartografia geologica in Italia. Rome: Tipografia della R. Accademia dei Lincei.

Quazza, Guido and Guazza Marisa (eds.) 1980. Epistolario di Quintino Sell. Vol. I, 1842-1865. Rome: Istituto per la Storia del Risorgimento Italiano.

Quazza, Guido and Guazza Marisa (eds.) 1984. Epistolario di Quintino Sell. Vol. II, 1866-1872. Rome: Istituto per la Storia del Risorgimento Italiano. 
Quazza, Guido and Guazza Marisa (eds.) 1991. Epistolario di Quintino Sell. Vol. III, 1870-1871. Rome: Istituto per la Storia del Risorgimento Italiano.

Quazza, Guido and Marisa (eds.) 1995. Epistolario di Quintino Sell. Vol. IV, 1872-1874. Rome: Istituto per la Storia del Risorgimento Italiano.

Quazza, Guido and Marisa (eds.) 1999. Epistolario di Quintino Sell. Vol. V, 1875-1878. Rome: Istituto per la Storia del Risorgimento Italiano, Archivio Guido Izzi.

Quazza, Guido 1992. L'utopia di Quintino Sella. La politica della scienza. Rome: Comitato di Torino dell'Istituto per la storia del Risorgimento italiano.

Sabella, Angelo 1959. Il Corpo delle Miniere nei suoi cento anni di vita. Faenza: Stabilimento Grafico F.lli Lega.

Savaton, Pierre 1998. La carte géologique dans l'enseignement secondaire. Bilan historique et didactique, réflexion et propositions d'apprentissage. Ph.D. dissertation, Université Paris VII.

Savi, Paolo and Meneghini, Giuseppe 1861. Considerazioni scientifico-tecniche. In Della legislazione mineraria e delle scuole delle Miniere, Enrico Poggi, Celso Marzucchi, Paolo Savi and Giuseppe Meneghin (eds.). Florence: Felice Le Monnier.

Secord, James 1986. The Geological Survey of Great Britain as a Research School, 1839-1855. History of Science 24: 233-275.

Sella, Quintino 1887. Sul modo di fare la Carta geologica d'Italia. In Discorsi parlamentari di Quintino Sella, 5 volumes, I: 637-671. Rome: Tipografia della Camera dei Deputati.

Sperandio, Sergio and Zanfrà, Silvana (eds.) 1997. Primi programmi per la carta Geologica d'Italia. Verbali delle adunanze del Regio Comitato Geologico d'Italia negli anni 1868-1877. Supplement to vol. 114, Bollettino del Servizio Geologico d'Italia. Rome: Istituto Poligrafico e Zecca dello Stato.

Stoppani, Antonio and Taramelli, Torquato 1880. Relazione e progetto di Legge presentati alla Commissione per la Carta Geologica del Regno. Florence: Le Monnier.

Taramelli, Torquato 1881. La carta Geologica d'Italia. Pavia: Stabilimento Tipografico Successori Bizzoni.

Tellini, Achille 1892. La Società Geologica Italiana. Origine e sviluppo. Rome: Rassegna delle scienze geologiche.

Todisco, A. 1988. Schema dell'attvità svolta dal Servizio Geologico Nazionale nel corso dell'anno 1988. Bollettino del Servizio Geologico d'Italia 107: 315-322.

Topley, William 1881. The Geological Survey of Italy. Nature, 24: 86-87

Topley, William 1885. The National Geological Surveys of Europe. London: Trübner.

Turner, Stephen P. 1990. The Survey in Nineteenth-Century American Geology: The Evolution of a Form of Patronage. Minerva 25: 282-330.

Vaccari, Ezio 1993. Giovanni Arduino (1714-1795): il contributo di uno scienziato veneto al dibattito settecentesco sulle scienze della Terra. Firenze: L.S. Olschki

Vaccari, Ezio (ed.) 1998. Le scienze della terra nel Veneto dell'Ottocento. Venice: Istituto Veneto di Scienze, Lettere e Arti.

Vai, Gian Battista 2002. Giovanni Capellini and the Origin of the International Geological Congresses. Episodes 25, 4: 248-254.

Vernizzi, Cristina (ed.) 1986. Quintino Sella tra politica e cultura 1827-1884. Atti del Convegno nazionale di studi. Turin: Silvestrelli e Cappelletto. 